\title{
The Use of Mobile Learning by Islamic Subject Students During Their Educational Preparation Program
}

\author{
Awad Ali Yahya Al-Qahtani \\ Department of Curriculum and Teaching Methods, Faculty of Education, Umm Al-Qura University, Makkah, Kingdom of Saudi Arabia \\ Email address: \\ aayq2005@gmail.com \\ To cite this article: \\ Awad Ali Yahya Al-Qahtani. The Use of Mobile Learning by Islamic Subject Students During Their Educational Preparation Program. \\ Higher Education Research. Vol. 3, No. 4, 2018, pp. 55-65. doi: 10.11648/j.her.20180304.11
}

Received: September 16, 2018; Accepted: October 23, 2018; Published: November 13, 2018

\begin{abstract}
The main question of this study is to what extent Islamic subject students in the faculty of education at Umm AlQura University use mobile learning in their educational preparation program. The following sub questions originate from the main question: 1- To what extent do Islamic subject students in the faculty of education at Umm Al-Qura University use mobile learning during the study of educational preparation program courses? 2-To what extent do Islamic subject students in the faculty of education at Umm Al-Qura University use mobile learning in their teacher training courses? The study sample consisted of all Islamic subject students in the educational preparation program in the faculty of education at Umm Al-Qura University in the second semester of the 2014-2015 academic year. A descriptive method was used to answer the questions of the study. After verifying its reliability and validity, a questionnaire was used to assess students' use of mobile learning in the educational preparation program. The results of the study revealed that the overall degree of Islamic subject students' use of mobile learning was medium with an arithmetic mean of (2.748). However, in terms of students' use of mobile learning during the study of educational preparation program courses, the results indicated that the degree of use was medium also with an arithmetic mean of (2.746). With regards to students' use of mobile learning in the teacher training course at schools, the results show that the degree of use was medium with an arithmetic mean of (2.752). However, based on these results, the researcher has managed to put forward a number of recommendations and suggestions.
\end{abstract}

Keywords: Mobile Learning, Islamic Subjects, Educational Preparation Program

\section{Introduction}

In the context of the functionality of technical development in the educational process, a new concept has appeared, mobile learning, which relies on the use of wireless technologies such as cell phones and laptops. Mobile learning is considered a form of distance learning, which is an umbrella that covers many concepts that have emerged with the use of technology in the educational process.

Mobile learning allows students to take advantage of technology in all times and places, and mobile phones have been shown to be used by the majority of students at all levels of education $[1,2]$.

The emergence of the mobile learning concept coincided with the emergence of many studies that examine its impact in improving and enhancing the educational process such as studies of Stone., Briggs \& Smith [3], Seppälä \& Alamäki [4], Corlett., Chan., Ting \& Sharples [5], Motiwalla [6],
Barak., Harward \& Lerman [7], Chen., Hsieh., \& Kinshu [8], Al- Dahshan \& Younis [9], Al-Harthy [10], Al-Fahad [11], Chen \& Huang [12], Al- Qahtani [13], Al- Juhani [14] AlShamrani [15], Asiri [16] and Khan [17]. A number of conferences have recommended and encouraged the use of mobile learning and to make use of its advantages in a variety of educational institutions and carrying out studies on the possibility of the employment and effectiveness of mobile learning in the educational process [18-20].

The stimuli for the conference's recommendations in this area - particularly in Saudi Arabia - where this author is located - were noted by Report on performance indicators for the telecommunications sector and information technology [21]: that there has been an increase in the use of mobile devices in Arab countries and in Saudi Arabia in particular and that the number of subscriptions to mobile communications services among various age groups approximately reached (52) million in the first months of the 
year (2013).

In this regard Seliaman \& Al-Turki [22] noted that the statistical reports confirm the growing demand of young people in the Kingdom of Saudi Arabia to use mobile phones and their different applications through the Web. The Kingdom of Saudi Arabia was classified as the highest ranked country in the use of mobile phones in the world.

Despite all this, this researcher believes that there is a shortage of studies in Saudi Arabia on the adoption and use of mobile learning in Saudi universities; therefore, this study was conducted to meet the shortfall of studies in this field.

In light of the above and in order to benefit from the latest technologies and technological innovations in the educational process, the current study seeks to shed light on the extent of use of mobile learning among the legitimate specialized students who are studying in the educational preparation program, College of Education at the University of Umm AlQura, Saudi Arabia; this study has two major sections:

The first section aims to determine the degree of use of mobile learning among the legitimate specialized students who are studying the syllabus of the educational preparation program, College of Education at the University of Umm AlQura, Saudi Arabia.

The second section aims to determine the degree of use of mobile learning among the legitimate specialized students who are studying in the educational preparation program, College of Education at the University of Umm Al-Qura, Saudi Arabia, during field training in general education schools.

\section{Mobile Learning}

Many definitions of mobile learning are found throughout the literature. This researcher will present some of these definitions; for example, Education Technology Forum defined mobile learning as "the link of e-learning systems with the modern mobile phones technology to introduce the knowledge and information and science via mobile phones"[23].

While Ghadian defined mobile learning as the use of portable devices linked to the Internet to learn as per student's time, place and abilities whether being synchronous or asynchronous [24].

As defined by Cochrane \& Flitta mobile learning is "the use of digital tools which designed in educational form within a learning environment and contexts" [25].

This type of learning has features that make it of a new pattern in the educational process, especially with wearable technologies such as (Google glass) and (Narrative clip). One of the advantages of mobile learning is that the student can interact with the parts of the educational process from any point without having to sit in front of a screen or in a classroom [26-29]. This feature has been highlighted by the results of several studies such as studies of Motiwalla [6], AlFahad [11] and Al-Khozaim [30]. Moreover, among the most prominent features of mobile learning was indicated by Khan that mobile learning facilitates the cooperation among students in all aspects of the educational process such as exchanging the educational content, activities and inquiries, using messages or calls or dialog through net-related mobile or wireless phones [17]. To take advantage of this feature, a team at Birmingham University conducted an experiment in (2005) on the application of mobile learning among a group of master's degree students to facilitate communication and cooperation among them, on the one hand, and between them and the teachers, on the other hand. Seppälä \& Alamäki performed a study to ensure the ability of teachers and student trainees to share their thoughts about the syllabus. The results showed the students' tendencies to share comments and observations via mobile phone messages [4].

Attewell [31] and Seibu \& Biju [32] also stated that one of the important advantages of using mobile learning in the educational process is the possibility of using mobile learning devices in recording observations and information, either by handwriting or voice register, as well as the ability to facilitate the collection of data, the editing and handling of data, and the search for information in and outside the classroom.

Rismark., Solvbery., Stromme., \&Hokstad added that mobile devices offer new opportunities for learning in higher education by providing continuous access to educational content management systems and programs [33].

However, despite the many advantages of mobile learning, it has many drawbacks.

AL-Dahshan stated the following drawbacks:

1. Limited storage capacity in mobile devices.

2. Weaker durability of mobile devices compared to that of personal computers.

3. Rapid development and succession of mobile phones, making them susceptible to rapid aging.

4. Limited screen size of mobile devices.

5. Misuse of mobile devices by some students if they are allowed within the schools and institutes.

6. Ongoing charging need of mobile devices due to the speed of running out of battery life [34].

After this brief presentation to highlight the advantages and disadvantages of mobile learning, it is worth noting that there are many challenges and difficulties that should be taken into consideration in order to activate and employ mobile devices in the educational process. Salem has stated the following challenges and difficulties:

1. The need for universities to adopt clear strategies for applying this new pattern of learning.

2. The provision of the necessary infrastructure, such as wireless networks and modern devices, for the application of mobile learning.

3. The design and preparation of courses to fit with mobile learning.

4. The provision of training and the necessary support for professors and students to employ mobile learning and its applications [35].

Notably, there are educational institutions in the Arab world that have overcome some of these difficulties and have carried out experiments and projects to activate mobile 
learning and its applications. One such project is the Arab Open University in Bahrain project, where the university has developed courses to be interactive and downloadable on mobile devices; the Higher Colleges of Technology project in the United Arab Emirates aims to benefit from the technical advantages of mobile phones and to make these devices available to college students [17].

Moreover, Tayba University in Saudi Arabia had a project for the development of the educational environment using mobile learning during the year of (2010), where the students were able to use the content management system in the university via their mobile phones [36].

Regarding Umm Al-Qura University-where the current study was conducted - recently, a service of mobile device support via the content management system was adopted by the university (Desire to Learn). The university represented by the Deanship of e-learning conducted several workshops to discuss ways to activate this system and challenges facing its implementation. To the best of the researcher's knowledge, this study is the first to identify to what extent Umm Al-Qura University students use mobile learning and take advantage of its features in the process of learning and teaching.

\section{Methodology of the Study}

In this study, the descriptive approach was used, which is the most widely used in the areas related to humanities studies. As Assaf stated, this approach depends on questioning all the research members or a large sample of them in order to describe the characteristics of the phenomenon under study in terms of its nature and degree of its presence [37]. Through this approach, the degree of the use of mobile learning among the Legitimate Specialty students in the College of Education at Umm Al-Qura University has been identified.

\subsection{Study Tools}

Since this study used a descriptive approach and its purpose was to identify the degree of use of mobile learning among the Legitimate Specialty students in the College of
Education, Umm Al-Qura University, a questionnaire was developed as a suitable tool for the study.

This tool was developed by the researcher after studying a range of Arabic and English literature about mobile learning, mobile devices and how to benefit from them in the educational process.

The questionnaire was preliminary designed with a total of (30) statements distributed in two sections. The first section related to the degree to which the Legitimate Specialty students at the College of Education at the University of Umm Al-Qura use mobile learning during their study of the educational preparation program. This section contains a total of (17) statements and one openended question. The open-ended question was for the respondent to add the usages and ways of taking advantage of mobile devices that were not mentioned within the closed statements. The second section was about the degree to which the legitimate discipline students in the College of Education at the University of Umm Al-Qura use mobile learning in teaching the students during the field application in schools. This section contains a total of (13) statements and one open-ended question. The open-ended question was for the respondent to add the usages and ways of taking advantage of mobile devices that were not mentioned within the closed statements.

A Likert scale with five options (always, often, sometimes, rarely, never) was used. In light of the comments and suggestions of a number of specialists in curriculums, teaching methods and educational technology, the modification of some of the statements was done in the final version of the questionnaire.

After ensuring the stability of the tool, the researcher applied a questionnaire pretest among a sample of (30) students. The reliability coefficient was calculated using (Cronbach's alpha) coefficient. The total value was (0.86). This value is considered a stable and satisfactory value, indicating acceptable internal consistency between the instrument statements. Table 1 shows the value of (Cronbach's alpha) of the instrument as a whole and for each of its sections separately.

Table 1. Cronbach's alpha coefficient values for the reliability of the study tool and its sections.

\begin{tabular}{lll}
\hline $\begin{array}{l}\text { Section of the tool: The degree of use of Legitimate (Shariah) Specialty students in the faculty of } \\
\text { education at the University of Umm Al-Qura for mobile learning: }\end{array}$ & $\begin{array}{l}\text { Number of } \\
\text { Statements: }\end{array}$ & $\begin{array}{l}\text { The value of Cronbach's } \\
\text { alpha coefficient: }\end{array}$ \\
\hline 1- During the study of the educational preparation program & 0.813 \\
2- In teaching students during field application in schools & 13 & 0.833 \\
3- The degree of total use of mobile learning by Legitimate Specialty students in the College of & 30 \\
Education at the University of Umm Al-Qura & 0.862 \\
\hline
\end{tabular}

The interrelated validity was also measured between the statements of the two sections of the instrument. The correlation value of the first section was $(0.81)$, while that for the second section was (0.86). Both values were statistically significant at the (0.01) level. Table 2 shows the interrelated validity between the statements of the two sections of the instrument.
Table 2. Results of correlative validity values * for statements of study tool sections.

\begin{tabular}{lllll}
\hline \multirow{2}{*}{$\begin{array}{l}\text { Statement } \\
\text { no. }\end{array}$} & \multicolumn{4}{l}{ Statement value correlation with total score average for } \\
\cline { 2 - 5 } & Section 1 & Total usage & Section 2 & Total usage \\
\hline 01 & $0.595^{* *}$ & $0.322^{*}$ & $0.517^{* *}$ & $0.422^{* *}$ \\
02 & $0.630^{* *}$ & $0.514^{* *}$ & $0.585^{* *}$ & $0.493^{* *}$ \\
03 & $0.630^{* *}$ & $0.454^{* *}$ & $0.454^{* *}$ & $0.473 * *$ \\
04 & $0.600^{* *}$ & $0.435^{* *}$ & $0.331^{*}$ & $0.379 *$ \\
\hline
\end{tabular}




\begin{tabular}{lllll}
\hline \multirow{2}{*}{$\begin{array}{l}\text { Statement } \\
\text { no. }\end{array}$} & \multicolumn{4}{l}{ Statement value correlation with total score average for } \\
\cline { 2 - 5 } & Section 1 & Total usage & Section 2 & Total usage \\
\hline 05 & $0.445^{* *}$ & $0.559^{* *}$ & $0.541^{* *}$ & $0.466^{* *}$ \\
06 & $0.598^{* *}$ & $0.591^{* *}$ & $0.604^{* *}$ & $0.572^{* *}$ \\
07 & $0.595^{* *}$ & $0.463^{* *}$ & $0.572^{* *}$ & $0.525^{* *}$ \\
08 & $0.514^{* *}$ & $0.521^{* *}$ & $0.665^{* *}$ & $0.681^{* *}$ \\
09 & $0.418^{* *}$ & $0.574^{* *}$ & $0.686^{* *}$ & $0.531^{* *}$ \\
10 & $0.314^{*}$ & $0.563^{* *}$ & $0.738^{* *}$ & $0.639^{* *}$ \\
11 & $0.580^{* *}$ & $0.425^{* *}$ & $0.766^{* *}$ & $0.541^{* *}$ \\
12 & $0.307^{*}$ & $0.303^{*}$ & $0.652^{* *}$ & $0.574^{* *}$ \\
13 & $0.618^{* *}$ & $0.544^{* *}$ & $0.306^{*}$ & $0.343^{*}$ \\
14 & $0.521^{* *}$ & $0.337^{*}$ & - & - \\
15 & $0.581^{* *}$ & $0.445^{* *}$ & - & - \\
16 & $0.314^{*}$ & $0.361^{*}$ & - & - \\
17 & $0.595^{* *}$ & $0.605^{* *}$ & - & - \\
Section 1 & - & - & $0.400^{* *}$ & $0.813^{* *}$ \\
Section 2 & - & - & - & $0.859^{* *}$ \\
\hline
\end{tabular}

(**) means that the correlation values contained in Table 2 are statistically significant at the level of $(0.01) .\left(^{*}\right)$ means that the correlation values contained in Table 2 are statistically significant at the level of $(0.05)$.

\subsection{Study Population}

The study population was composed of all students enrolled in the Legitimate Specialty at Umm Al-Qura University who are studying the preparatory education program in the faculty of education for the second semester of 2015. Due to the small number of the study population, the study was conducted among all (93) students.

\section{Study Results and Discussion}

To answer the study questions, the statistical process of the data frequencies, percentage and means was completed with the use of the statistical package program (SPSS).

The presentation and discussion of the study results was shown as per the percentages and means in light of the fifth scale presented in Table 3 below.

Table 3. The scale of judging study results.

\begin{tabular}{lll}
\hline The degree of use & Arithmetic average value & Percentage \\
\hline Always (i.e., use at very high degree) & $4.20-5$ & $84-100 \%$ \\
Often (i.e., use at high degree) & less than $3.40-4.20$ & less than $68-84 \%$ \\
Sometimes (i.e., use at medium degree) & less than $2.60-3.40$ & less than $52-68 \%$ \\
Rarely (i.e., use at weak degree) & less than $1.80-2.60$ & less than $36-52 \%$ \\
Never (i.e., use at too weak degree) & less than $0-1.80$ & less than $0-36 \%$ \\
\hline
\end{tabular}

The results showed the following:

The first question states the following:

To what extent do the Legitimate Specialty students at Umm Al-Qura University use mobile learning while studying the preparatory education program?

To answer this question, the statistical analysis of the study population's responses to the statements under this section was done in light of means and percentages. Table No. 4 below shows the means of student use of mobile learning while studying the preparatory education program (in descending order according to means and percentages).

Table 4. The degree of use of mobile learning among the Legitimate Specialty students studying the syllabus of the educational preparation program, College of Education at the University of Umm Al-Qura, Saudi Arabia. (Arranged in descending order according to averages and percentages.).

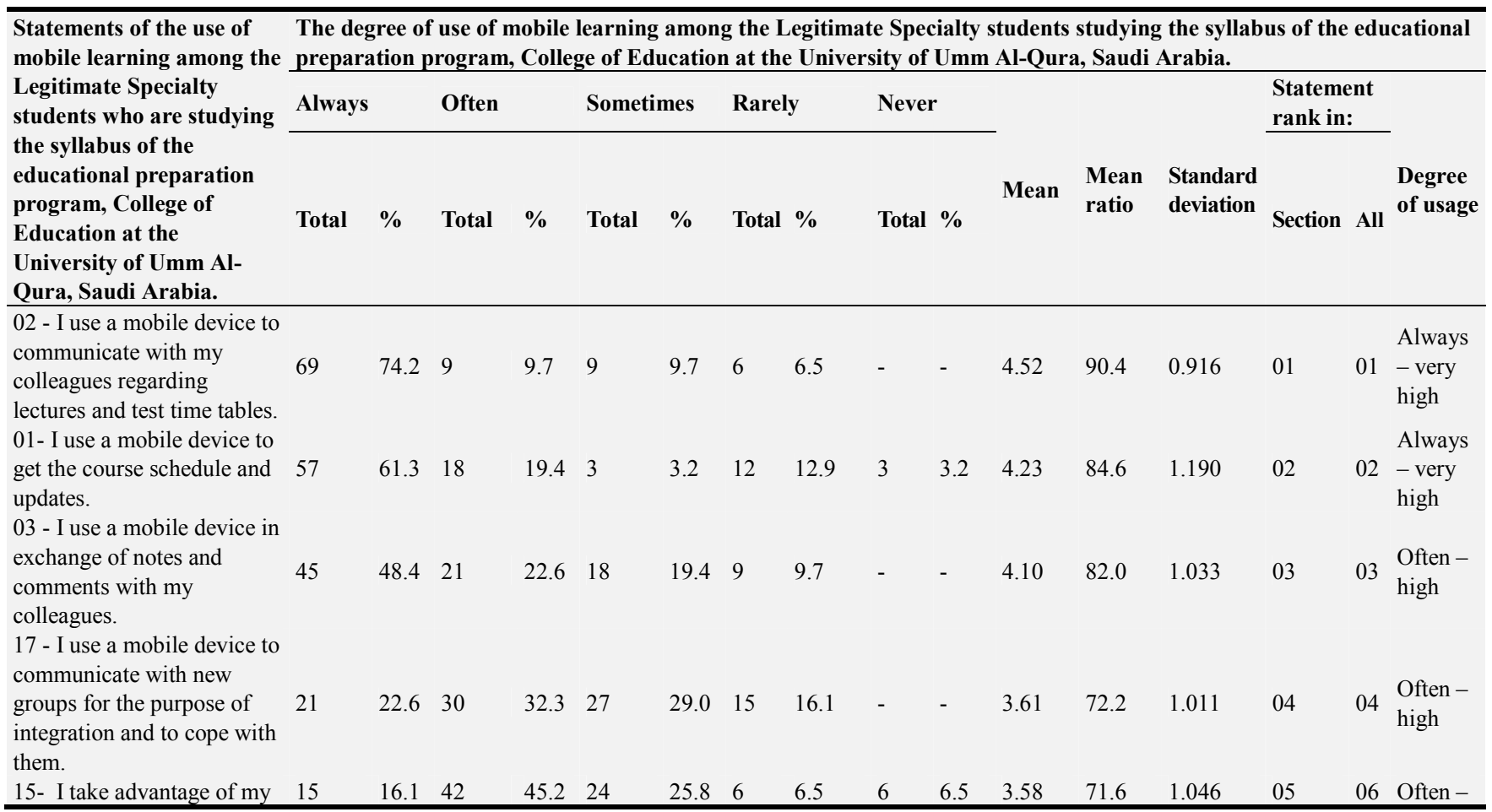




\begin{tabular}{|c|c|c|c|c|c|c|c|c|c|c|c|c|c|c|c|c|}
\hline \multirow{3}{*}{$\begin{array}{l}\text { Statements of the use of } \\
\text { mobile learning among the } \\
\text { Legitimate Specialty } \\
\text { students who are studying } \\
\text { the syllabus of the } \\
\text { educational preparation } \\
\text { program, College of } \\
\text { Education at the } \\
\text { University of Umm Al- } \\
\text { Qura, Saudi Arabia. }\end{array}$} & \multicolumn{16}{|c|}{$\begin{array}{l}\text { The degree of use of mobile learning among the Legitimate Specialty students studying the syllabus of the educational } \\
\text { preparation program, College of Education at the University of Umm Al-Qura, Saudi Arabia. }\end{array}$} \\
\hline & Alway & & Often & & Somet & mes & Rare & & Neve & & & & & $\begin{array}{l}\text { Stateme } \\
\text { rank in: }\end{array}$ & & \\
\hline & Total & $\%$ & Total & $\%$ & Total & $\%$ & Total & $\%$ & Total & $\%$ & Mean & $\begin{array}{l}\text { Mean } \\
\text { ratio }\end{array}$ & $\begin{array}{l}\text { Standard } \\
\text { deviation }\end{array}$ & Section & All & $\begin{array}{l}\text { Degree } \\
\text { of usage }\end{array}$ \\
\hline $\begin{array}{l}\text { mobile device to discuss } \\
\text { with my colleagues and my } \\
\text { teachers urgent issues } \\
\text { related to the course. }\end{array}$ & & & & & & & & & & & & & & & & high \\
\hline $\begin{array}{l}\text { 16- I share with my } \\
\text { colleagues some of the } \\
\text { difficulties that I face using } \\
\text { my mobile device. }\end{array}$ & 21 & 22.6 & 36 & 38.7 & 15 & 16.1 & 12 & 12.9 & 9 & 9.7 & 3.52 & 70.4 & 1.248 & 06 & 07 & $\begin{array}{l}\text { Often - } \\
\text { high }\end{array}$ \\
\hline $\begin{array}{l}\text { 04- I use my mobile device } \\
\text { to communicate with the } \\
\text { instructor and ask questions } \\
\text { and inquiries. }\end{array}$ & 18 & 19.4 & 3 & 3.2 & 30 & 32.3 & 33 & 35.5 & 9 & 9.7 & 2.87 & 57.4 & 1.244 & 07 & 12 & $\begin{array}{l}\text { Someti } \\
\text { mes - } \\
\text { medium }\end{array}$ \\
\hline $\begin{array}{l}\text { 13- I use my mobile device } \\
\text { to enter the instructor's page } \\
\text { on the university website } \\
\text { and download materials and } \\
\text { do various activities. }\end{array}$ & 12 & 12.9 & 9 & 9.7 & 27 & 29.0 & 18 & 19.4 & 27 & 29.0 & 2.58 & 51.6 & 1.346 & 08 & 14 & $\begin{array}{l}\text { Rarely - } \\
\text { weak }\end{array}$ \\
\hline $\begin{array}{l}\text { 08- I use my mobile device } \\
\text { to send what is required by } \\
\text { the course professor } \\
\text { electronically. }\end{array}$ & 6 & 6.5 & 9 & 9.7 & 24 & 25.8 & 33 & 33.5 & 21 & 22.6 & 2.42 & 48.4 & 1.136 & 09 & 18 & $\begin{array}{l}\text { Rarely - } \\
\text { weak }\end{array}$ \\
\hline $\begin{array}{l}14 \text { - I use my mobile device } \\
\text { to navigate and research } \\
\text { databases available on the } \\
\text { website of the university } \\
\text { library. }\end{array}$ & 9 & 9.7 & 15 & 16.1 & 12 & 12.9 & 18 & 19.4 & 39 & 41.9 & 2.32 & 46.4 & 1.408 & 10 & 20 & $\begin{array}{l}\text { Rarely - } \\
\text { weak }\end{array}$ \\
\hline $\begin{array}{l}\text { 07- I browse through the } \\
\text { comments and notes I write } \\
\text { about lectures on my mobile } \\
\text { device. }\end{array}$ & 3 & 3.2 & 9 & 9.7 & 18 & 19.4 & 42 & 45.2 & 21 & 22.6 & 2.26 & 45.2 & 1.020 & 11 & 22 & $\begin{array}{l}\text { Rarely - } \\
\text { weak }\end{array}$ \\
\hline $\begin{array}{l}05 \text { - I use my mobile device } \\
\text { to take notes during the } \\
\text { lecture. }\end{array}$ & 3 & 3.2 & - & - & 30 & 32.3 & 42 & 45.2 & 18 & 19.4 & 2.23 & 44.6 & 0.874 & 12 & 23 & $\begin{array}{l}\text { Rarely - } \\
\text { weak }\end{array}$ \\
\hline $\begin{array}{l}\text { 11- I use my mobile device } \\
\text { during lectures to search } \\
\text { about some ideas under } \\
\text { discussion. }\end{array}$ & - & - & 9 & 9.7 & 21 & 22.6 & 36 & 38.7 & 27 & 29.0 & 2.13 & 42.6 & 0.947 & 13 & 24 & $\begin{array}{l}\text { Rarely - } \\
\text { weak }\end{array}$ \\
\hline
\end{tabular}

Table 4. Continued.

\begin{tabular}{|c|c|c|c|c|c|c|c|c|c|c|c|c|c|c|c|c|}
\hline \multirow{3}{*}{$\begin{array}{l}\text { Statements of the } \\
\text { use of mobile } \\
\text { learning among the } \\
\text { Legitimate Specialty } \\
\text { students studying } \\
\text { the syllabus of the } \\
\text { educational } \\
\text { preparation } \\
\text { program, College of } \\
\text { Education at the } \\
\text { University of Umm } \\
\text { Al-Qura, Saudi } \\
\text { Arabia. }\end{array}$} & \multicolumn{16}{|c|}{$\begin{array}{l}\text { The degree of use of mobile learning among the Legitimate specialty students studying the syllabus of the educational } \\
\text { preparation program, College of Education at the University of Umm Al-Qura, Saudi Arabia. }\end{array}$} \\
\hline & Always & & Often & & Somet & nes & Rarely & & Never & & & & & $\begin{array}{l}\text { Stateme } \\
\text { rank in: }\end{array}$ & & \\
\hline & Total & $\%$ & Total & $\%$ & Total & $\%$ & Total & $\%$ & Total & $\%$ & Mean & $\begin{array}{l}\text { Mean } \\
\text { ratio }\end{array}$ & $\begin{array}{l}\text { Standard } \\
\text { deviation }\end{array}$ & Section & All & $\begin{array}{l}\text { Degree } \\
\text { of usage }\end{array}$ \\
\hline $\begin{array}{l}\text { 10- I review codified } \\
\text { notes from previous } \\
\text { lectures on my } \\
\text { mobile device before } \\
\text { entering the next }\end{array}$ & - & - & 9 & 9.7 & 15 & 16.1 & 21 & 22.6 & 48 & 51.6 & 1.84 & 36.8 & 1.025 & 14 & 27 & $\begin{array}{l}\text { Rarely - } \\
\text { weak }\end{array}$ \\
\hline
\end{tabular}




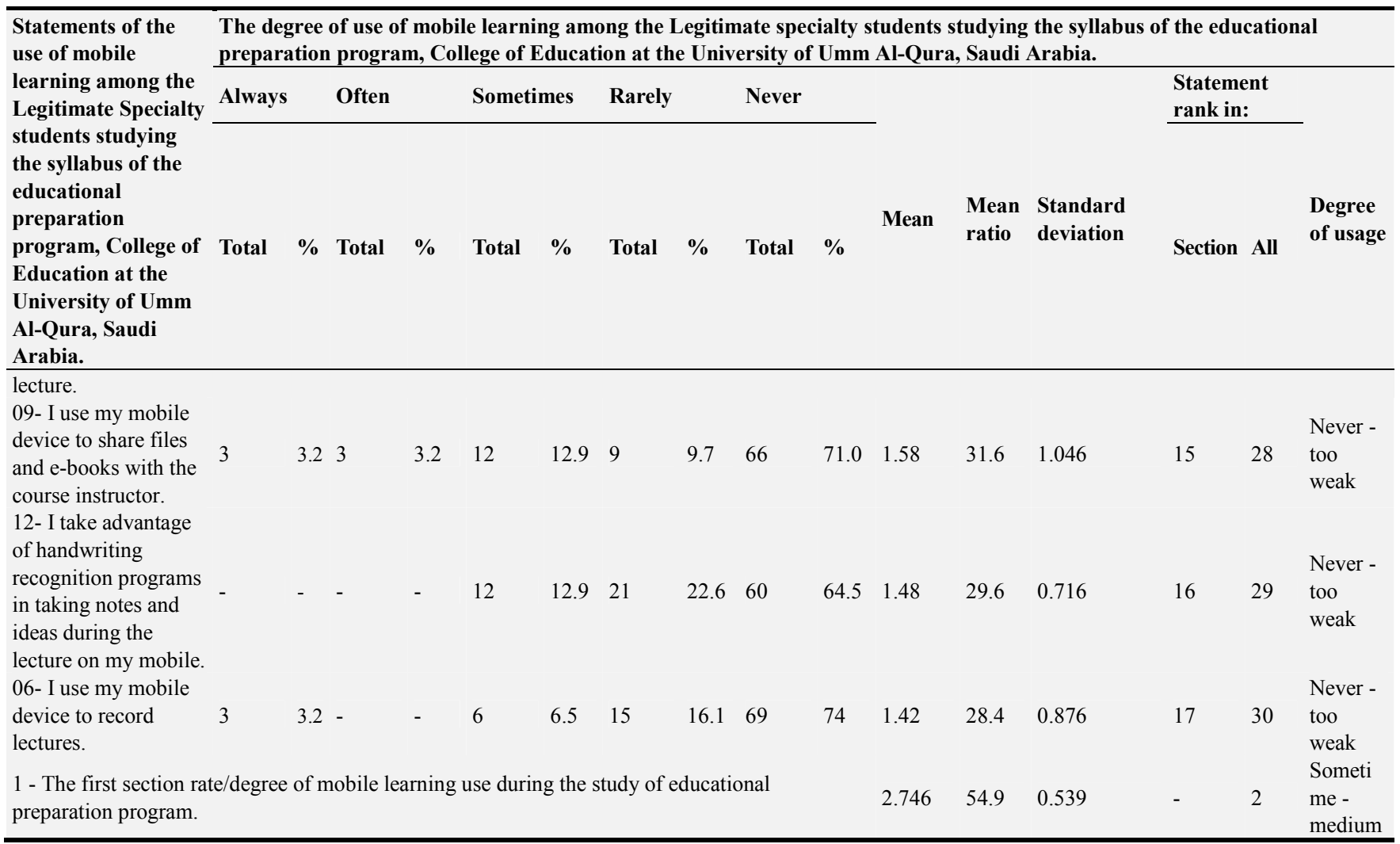

Table 4 above shows the results of the first section; these results reflect that the usage degree of mobile learning during the study of the educational preparation program was not high among the Legitimate Specialty students in the College of Education at the University of Umm Al-Qura. The value of the arithmetic average of the application for the whole first section was (2.746) and the percentage was (54.9). This value is medium according to the scale of judging the study results shown in Table 2. This value, despite being medium, did not reach the desired level of adopting mobile learning and benefiting from the smart mobile devices while teaching the university students. It is quite apparent from the means and percentages of the statements of this section that most of the statements related to making use of mobile devices in the educational process by students themselves were very high or high, such as statements $(1,2,3,15,16,17)$, while most of the statements that reflect the faculty member application and benefit from mobile learning in the educational process such as statements $(8,9,13)$ were weak or very weak. This means that student interaction with mobile learning and the benefit of smart mobile devices during the study of the educational preparation program are greater than the interaction of faculty members with mobile learning. This might be due to the superiority of students' electronic technical culture and the use of new mobile devices that gives students an advantage compared to faculty members.

Statements $(5,6,7,10,11,12)$ also came with weak or too weak degree of use; although these are student-related statements, the instructor is also involved in their activation and employment in the educational process. Most faculty members do not allow students to bring smart devices in the lecture and do not allow them to use smart devices during lecture time for taking notes, recording or searching and so on.

More specifically, it is clear from Table 4 that the students' use of mobile devices to communicate with their colleagues regarding lectures and test timetables, course schedule, updates, course notes, exchange of comment, discussions of some urgent issues and difficulties they face during the study as well as integrating and coping with new groups all attained high or very high degree of use.

However, the use of mobile devices to access the instructor web page to download materials or to accomplish certain activities as well as the use of mobile devices to take notes, record lectures or exchange files with the instructor all scored weak or very weak degree of use.

We conclude therefore that whether the faculty member benefits from mobile devices during university teaching is still in doubt and that most faculty members at the university prevent students from using mobile devices during lectures to take notes. In addition, most faculty members do not activate their web pages on the university website as required; therefore, the students could benefit from instructor webpages and from using their mobile devices through the content management system adopted by Umm Al-Qura University (D2 L), which supports mobile learning.

Furthermore, the students' use of mobile devices to navigate and research databases available on the website of the university library had a weak degree of use. This was reflected in the score of statement (14), as shown in Table 4. The mean value of this statement was (2.32). This low degree of use of mobile devices to search for knowledge through 
available sources might refer to the inadequate training of students in this area. The researcher, throughout his several years of teaching experience of the method of Islamic education (1) and (2) as well as teaching the course in designing school activities in Islamic education subjects, found that some students do not know that the content management system of the university website supports the use of mobile devices and that most students are unaware of the steps to access the databases that support their specialty.

Table 4 also shows that the only statement that reflects a medium degree of use of mobile devices is statement number (4), which states that "I use my mobile device to communicate with the instructor and ask questions and inquiries"; this statement had an arithmetic mean of (2.87). Although some course instructors do not favor this mode of communication, communication in this way is done through the instructor mobile number located on his webpage through the university website via SMS messages or (WhatsApp).

Notably, mobile learning in Saudi Arabia is still in its early stages at many universities, as mentioned by Nassuora [35].
However, students' positive attitudes toward this type of learning, as evidenced by studies of Al-Fahad [11], Paul [39], Liaw., Hatala., \& Huang [40], Singh [41], Nassuora [38] and Yang [42] makes it imperative to strive to activate mobile learning in universities and to take actions to encourage faculty members to adopt and activate mobile learning in the teaching process.

The second question states the following:

To what extent do the Legitimate Specialty students in the College of Education at Umm Al-Qura University use mobile learning during the field application in schools?

To answer this question, the study population answered the statements of this section, which were analyzed in light of the arithmetic mean and percentage values. Table 5 below shows the mean values of using mobile learning during the field application in schools of the Legitimate Specialty students in College of Education at Umm Al-Qura University. (Statements were arranged in descending order according to means and percentages).

Table 5. The Degree of Using Mobile Learning During the Field Application in Schools by Members of the Study Population Consisting of Legitimate Specialty Students in the College of Education at Umm Al-Qura University. (Arranged in Descending Order According to Means and Percentages.).

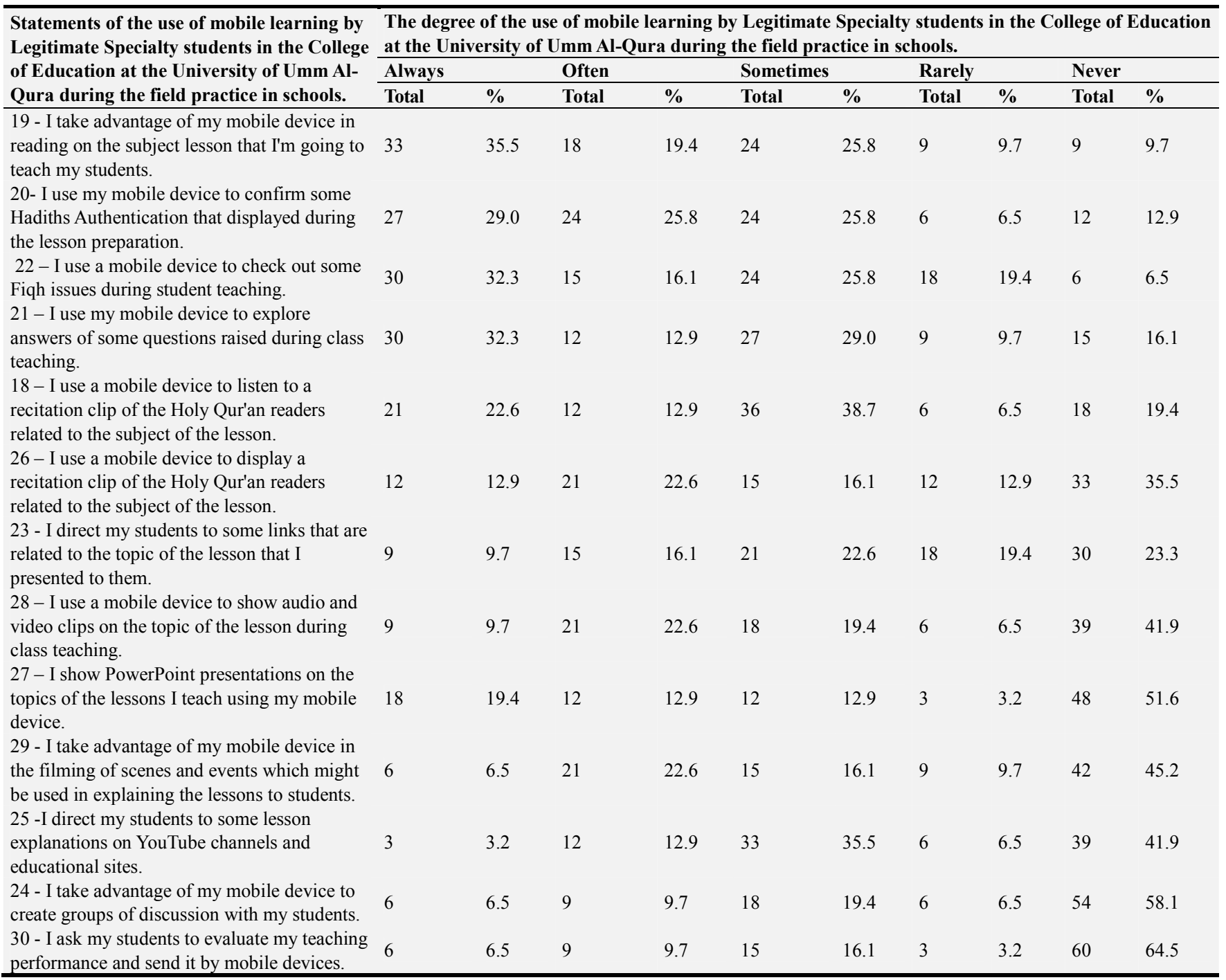


Table 5. Continued.

\begin{tabular}{|c|c|c|c|c|c|c|}
\hline \multirow{3}{*}{$\begin{array}{l}\text { Statements of the use of mobile learning by Legitimate } \\
\text { Specialty students in the College of Education at the } \\
\text { University of Umm Al-Qura during the field practice } \\
\text { in schools. }\end{array}$} & \multicolumn{6}{|c|}{$\begin{array}{l}\text { The degree of the use of mobile learning by Legitimate Specialty students in the College } \\
\text { of Education at the University of Umm Al-Qura during the field practice in schools. }\end{array}$} \\
\hline & \multirow{2}{*}{ Mean } & \multirow{2}{*}{ Mean Ratio } & \multirow{2}{*}{$\begin{array}{l}\text { Standard } \\
\text { Deviation }\end{array}$} & \multicolumn{2}{|c|}{ Statement Rank in: } & \multirow{2}{*}{ Degree of Usage } \\
\hline & & & & Section & All & \\
\hline $\begin{array}{l}19 \text { - I take advantage of my mobile device in reading on } \\
\text { the subject lesson that I'm going to teach my students. }\end{array}$ & 3.61 & 72.2 & 1.319 & 01 & 05 & Often - high \\
\hline $\begin{array}{l}\text { Authentication that displayed during the lesson } \\
\text { preparation. }\end{array}$ & 3.52 & 70.4 & 1.324 & 02 & 08 & Often - high \\
\hline $\begin{array}{l}22 \text { - I use a mobile device to check out some Fiqh issues } \\
\text { during student teaching. }\end{array}$ & 3.48 & 69.6 & 1.299 & 03 & 09 & Often - high \\
\hline $\begin{array}{l}21 \text { - I use my mobile device to explore answers of some } \\
\text { questions raised during class teaching. }\end{array}$ & 3.35 & 67.0 & 1.434 & 04 & 10 & $\begin{array}{l}\text { Sometimes - } \\
\text { medium }\end{array}$ \\
\hline $\begin{array}{l}18 \text { - I use a mobile device to listen to a recitation clip of } \\
\text { the Holy Qur'an readers related to the subject of the } \\
\text { lesson. }\end{array}$ & 3.13 & 62.6 & 1.369 & 05 & 11 & $\begin{array}{l}\text { Sometimes - } \\
\text { medium }\end{array}$ \\
\hline $\begin{array}{l}26 \text { - I use a mobile device to display a recitation clip of } \\
\text { the Holy Qur'an readers related to the subject of the } \\
\text { lesson. }\end{array}$ & 2.65 & 53.0 & 1.479 & 06 & 13 & $\begin{array}{l}\text { Sometimes - } \\
\text { medium }\end{array}$ \\
\hline $\begin{array}{l}23 \text { - I direct my students to some links that are related to } \\
\text { the topic of the lesson that I presented to them. }\end{array}$ & 2.52 & 50.4 & 1.348 & 07 & 15 & Rarely - weak \\
\hline $\begin{array}{l}28 \text { - I use a mobile device to show audio and video clips } \\
\text { on the topic of the lesson during class teaching. }\end{array}$ & 2.52 & 50.4 & 1.464 & 08 & 16 & Rarely - weak \\
\hline $\begin{array}{l}27 \text { - I show PowerPoint presentations on the topics of the } \\
\text { lessons I teach using my mobile device. }\end{array}$ & 2.45 & 49.0 & 1.652 & 09 & 17 & Rarely - weak \\
\hline $\begin{array}{l}29 \text { - I take advantage of my mobile device in the filming } \\
\text { of scenes and events which might be used in explaining } \\
\text { the lessons to students. }\end{array}$ & 2.35 & 47.0 & 1.411 & 10 & 19 & Rarely - weak \\
\hline $\begin{array}{l}25 \text {-I direct my students to some lesson explanations on } \\
\text { YouTube channels and educational sites. }\end{array}$ & 2.29 & 45.8 & 1.230 & 11 & 21 & Rarely - weak \\
\hline $\begin{array}{l}24 \text { - I take advantage of my mobile device to create } \\
\text { groups of discussion with my students. }\end{array}$ & 2.00 & 40.0 & 1.327 & 12 & 25 & Rarely - weak \\
\hline $\begin{array}{l}30 \text { - I ask my students to evaluate my teaching } \\
\text { performance and send it by mobile devices. }\end{array}$ & 1.90 & 38.0 & 1.336 & 13 & 26 & Rarely - weak \\
\hline $\begin{array}{l}2 \text { - The second section rate/degree of mobile learning use } \\
\text { during the field application in school }\end{array}$ & 2.752 & 55.2 & 0.800 & - & 1 & $\begin{array}{l}\text { Sometimes - } \\
\text { medium }\end{array}$ \\
\hline
\end{tabular}

As seen from Table 5 above, the value of the arithmetic average of the Legitimate Specialty students in the College of Education at Umm Al-Quran University for using mobile learning during field application in schools for the whole second section was (2.752). This value, although higher than the arithmetic average of the first section, is a moderate value and below the required level of employing mobile devices and benefit from them during the student's field application in the schools. None of the statements in this section got a very high score, while only three statements, statements (19, 20,22 ), got a high degree of use.

The three statements mentioned previously regard the preparation of class teaching. Statement number (19) refers to the advantage of the mobile device to read on the subject of the lesson that the student teacher will present to his students, whereas statement number (20) refers to the use of mobile devices to confirm some Hadiths' Authentication that displayed during the lesson preparation. Statement number (22) refers to the use of the mobile device to review some Fiqh (Jurisprudence) issues on the subject's lesson.

There is no doubt that the high score of the statements related to the preparation of the class teaching emphasizes the benefit of mobile devices in the possibility of continuous easy reach to the knowledge sources without having to bother about sitting in a specific place to open a desktop device and link it to the Internet and to access knowledge, searching and seeking more sources on a particular topic. This finding is supported by the study of Rismark., Solvbery., Stromme., \& Hokstad [33].

Table 5 also shows that the statements that related to the use and benefit of mobile devices during class teaching ranged between a medium degree of use, such as statements $(18,21,26)$, and a weak degree of use, such as statements $(27,28,29)$.

Statement number (21), which stated that "I use my mobile device to explore answers of some questions raised during class teaching", had an arithmetic mean of (3:35). Statements (18) and (26), which refer to the use of mobile devices to listen and view recitation clips of the Holy Qur'an readers about the subject of the lesson, had means of (3.13), (2.65), respectively, while statement number (28), which refers to the use of the mobile device in the presentation of audio and video clips on the topic of the lesson during class teaching, was scored a weak degree of use with an arithmetic average of (2.52). Statement number (27), which stipulates that "I show PowerPoint presentations on the topics of the lessons I teach using my mobile device" had a weak degree of use with an average arithmetic of (2.45). 
Statement number (29) also had a weak degree of use with an arithmetic mean of (2.35). This statement stipulates that "I take advantage of my mobile device in the filming of scenes and events which might be used in explaining the lessons to students". This decline in the use of mobile devices during class teaching might be due to first the weakness of preparing the student teacher in this important aspect. Only one course, under the name of Teaching Aids, with respect to technology was offered to students in the educational preparation program. The course vocabulary and name are old and need to be developed. Second, communication networks are poor and sometimes nonexistent in some schools. This is undoubtedly one of the difficulties in implementing mobile learning and benefiting from mobile devices in the educational process, as noted by Salem [35].

Also, it is apparent from Table 5 that the statements related to students' direction to make use of mobile devices after presenting the educational session, all came with a weak degree of use. Those were statements $(23,24,25,30)$.

Statement number (23), which states that "I direct my students to some links that are related to the topic of the lesson that I presented to them", had an arithmetic average of (2.52). This value is weak according to the scale of judging results agreed upon in the study. In addition, statement (25) came with a weak value and an arithmetic average of (2.29); this statement stipulated that "I direct my students to some lesson explanations on YouTube channels and educational sites". This means that the use of mobile devices to transfer and extend the learning process outside the classroom environment is below the desired level. The results of the experimental study carried out by Swan., HooftMarkvan 't., Kratcoski., \& Unger to explore the students use of mobile devices showed that mobile devices support the privacy of learning and extend the learning process outside of school [43].

The results of statements (24) and (30) also showed a weak degree of use. The arithmetic mean value was (2.00) for statement number (24), which states "I take advantage of my mobile device to create groups of discussion with my students". Statement number (30), which states "I ask my students to evaluate my teaching performance and send it by mobile devices", had the lowest value of this section's statements with a mean of (1.90).

\section{Conclusion}

This study examines to what extent Legitimate Specialty students - involved in the educational preparation program in the faculty of education at Umm Al-Qura University-use mobile learning.

After analyzing the student responses to the study statements contained in the study tool (questionnaire), the results show that the overall score of using mobile learning among the Legitimate Specialty students was moderate. The results of the study also show that the score of student usage of mobile learning during the theoretical courses in the educational preparation program was moderate. With regard to student usage of mobile learning during field application, the results of the study indicated that it was moderate.

When looking in more detail into the analysis of the study population responses on the section statements, it clearly shows the following:

- More than half of the first section's statements (the degree of student use of mobile learning during the study of theoretical courses in the educational preparation program), (10) out of (17) statements, had a weak or very weak degree of use. This finding requires that the instructors of these courses reconsider the ways and methods of teaching these courses. Most of these statements related to the instructor employment of mobile learning while teaching the students. The Deanship of training and development at the Umm AlQura University has to take the results of this study into account and to include training programs for faculty members on how to take advantage of the content management program software (D2 L), which has been adopted by the University, in the functionality of mobile learning in the educational process; in addition, the Deanship must urge and motivate faculty members to attend these courses.

- The results also showed that more than half the second section's statements (the degree of students' use of mobile learning during field application in schools), (7) out of (13) statements, had a weak degree of use. These results suggest the need to review the courses that introduce the use of technology to the students enrolled in the educational preparation program and to work to develop these courses to cope with the development of technology and to find ways to benefit from technology in the educational process.

This study focused on the degree of use of mobile learning among the Legitimate Specialty students enrolled in the educational preparation program, and there is no doubt that the expansion of the study population to include other specialties will give a clearer and more comprehensive picture of the degree of mobile learning employment in the teaching of the educational preparation program in the faculty of education at the University of Umm Al-Qura.

\section{References}

[1] Lal, Zakaria, Yahia. (2011). Modern technology in the education of mentally superior. Cairo: the world of books.

[2] Quresh, F. Y. (2017). Opening the Doors For Mobile Assisted Language Learning Mobile Apps For ESL: Value and Methods. Journal of Al-Quds Open University for Research and Studies, No. 42-part (1)- Safar, pp. 22-34.

[3] Stone, A., Briggs, J., \& Smith, C. (2002). SMS and Interactivity Some Results from the field, and its Implications on Effective Uses of Mobile Technologies in Education. IEEE international Workshop on Wireless and Mobile Technologies in Education, Vaxjo, Sweden. 147-151.

[4] Seppälä, P., \& Alamäki, H. (2003). Mobile learning in teacher training, Journal of Computer Assisted Learning, No.19, pp. 330-335. 
[5] Corlett, D. Chan, T. Ting, J., \& Sharples, M. (2005). Interactive Logbook: a Mobile Portfolio and Personal Development Planning Tool. Mobile Technology: The future of learning in your hands, Cape Town, South Africa, 32-36.

[6] Motiwalla, L. F. (2007). 'Mobile learning: A framework and evaluation', Computers \& Education. 49: 581-596.

[7] Barak, M; Harward, J. and Lerman, S. (2007). Studio- based learning via wireless notebooks: a case of a Java programming course, Int. J. Mobile Learning and Organization, Vol, 1, No. 1, pp. 15-29.

[8] Chen, N. S., Hsieh, S. W., \& Kinshu, K. (2008). Effects of Short-Term Memory and Content Representation Type on Mobile Language Learning. Knowledge Management World Conference. Santa Clara, USA.

[9] Al- Dahshan, Jamal Ali., and Younis, Magdi, Mohammed. (2009). Education through mobile is a new formula for distance education, the first scientific symposium on the Department of Education and the Comparison and Management education: " The Assumed higher education systems", Faculty of Education, University of Kafr El-Sheikh, Egypt, April 29.

[10] Al-Harthy, Mohamed, Attia. (2009). Model for the application of mobile education at King Saud University, The online documentation management forum, the Library and Information Association, Riyadh, 5-6 October.

[11] Al-Fahad, Fahad, N. (2009). Student's attitudes \& Perceptions Towards the effectiveness of Mobile Learning in King Saud University, Saudi Arabia, The Turkish Online Journal of Educational Technology-TOJET, April 2009. ISSN: 13036521, volume 8, Issue 2, Article 10.

[12] Chen, H. R., \& Huang, H. L. (2010). User acceptance of mobile knowledge management learning system: design and analysis. Educational Technology \& Society, 13 (3), 70-77.

[13] Al- Qahtani, Sana, Saeed. (2011). The impact of mobile learning on the development of critical thinking skills, the Second International Conference on e-Learning and Distance Education, National Center for e-learning and distance education, Riyadh, February 21- 24.

[14] Al- Juhani, Leila, Said. (2013). The effectiveness of mobile learning via SMS in teaching some of the e-learning concepts and themes for the students of Childhood Studies, working paper submitted to the Third International Conference on elearning and distance learning, Riyadh.

[15] Al-Shamrani, Ali, Abdullah, Zayed. (2013). The importance of the use of smart phones and tablet PCs to support the learning of English among secondary school students. Unpublished Master Thesis, Curriculum and Instruction Department, College of Education, Umm Al Qura University, Makkah.

[16] Asiri, Idris, Rashid, Idris. (2014). The importance of using mobile phones and computers in the teaching of biology from the perspective of the educational supervisors and teachers of biology at Mahayel Asir governorate. Unpublished MA Thesis, Curriculum and Instruction Department, College of Education, Umm Al Qura University, Makkah.

[17] Khan, Amal, Abdul Malik. (2014). The effectiveness of mobile learning based on the web via the computers in mathematics course on the achivement of fifth-grade students. Unpublished MA Thesis, Curriculum and Instruction
Department, College of Education, Umm Al Qura University, Makkah.

[18] First International Conference on E-Learning and Blended Education as a Strategic Choice for Arab Universities, November 13-15, 2012, Philadelphia University, Jordan, Available online

http://www.philadelphia.edu.jo/ICELBE2012/.

[19] The International Conference for Learning and Teaching in the Digital World: Learning from other nations, 31 March 2014, An-Najah University, Palestine, Available online at: https://www.najah.edu/en/news-archive/the-internationalconference-for-learning-and-teaching-in-the-digital-worldlearning-from-other-nations/.

[20] The Third International Conference on e-Learning and Distance Education, 3rd to 6th February 2013, National Center for e -Learning \& Distance Learning, Riyadh, Saudi Arabia, Available online at: https://conferencealerts.com/show-event?id=101354.

[21] Communications and Information Technology Commission. (2013). Report on performance indicators for the telecommunications sector and information technology. (The first quarter of 2013). Available at: http://goo.gl/AU6KmR. Retrieved on 01/08/2016.

[22] Seliaman, M, E; \& Al-Turki, M, S. (2012). Mobile Learning Adoption in Saudi Arabia. World Academy of Science, Engineering and Technology, Vol. 69, pp. 356-358.

[23] Education Technology Forum. (2011). Available on the link: http: //education.own0.com/t247.

[24] Ghadian, Mohsen, Abdul Razak. (2012). a proposal of Mobile Learning in higher education institutions. Journal of the Future of the Arab Education. Vol. 20, pp. 82.

[25] Cochrane, T., \& Flitta, L. (2009). An M Learning Journey: Critical Incidant In Transforming Pedagogy, Proceedings of Icerl 2009 Conference Spain: Madrid.

[26] Hwang, G. J., \& Tsai, C. C. Research trend in mobile and ubiquitous learning: a review of publications in selected journal from 2001 to 2010. British Journal of Education Technology, 42 (4), 2011. E65-E70

[27] Elfeky, A. I. M., \& Masadeh, T. S. Y. (2016). The Effect of Mobile Learning on Students' Achievement and Conversational Skills. International Journal of Higher Education, 5 (3), 20-31.

[28] Huang, C. S., Yang, S. J., Chiang, T. H., \& Su, A. Y. (2016). Effect of Situated Mobile Learning Approach on Learning Motivation and Performance of EFL Students. Educational Technology \& Society, 19 (1), 263-276.

[29] Abu Laban, Mousa, Mahmoud. (2017). The Effectiveness of Using Mobile Learning in Developing Eleventh Graders' English Grammar Learning and Motivation for English. Unpublished Dissertation, Gaza, Palestine.

[30] Al-Khozaim, Khalid, Muhammad. (2012). The effectiveness of the use of Blackboard for Mobile learning in the development of students' interaction and academic achievement in course of teaching methods of mathematics in Teachers College at King Saud University. Unpublished PhD thesis, Curriculum and Instruction department, Faculty of Social Sciences, Imam Muhammad bin Saud Islamic University, Riyadh. 
[31] Attewell, J. (2005). Mobile Technologies and Learning: a technology update and m-learning project summary. Report, Learning and Skills Development Agency.

[32] Seibu, J., \& Biju, I., (2008). Mobile Technologies and Its Impact- An Analysis in Higher Education Context, International Journal of Interactive Mobile Technologies, Vol. 2, No. 1, pp. 17.

[33] Rismark, M., Solvbery, A. M., Stromme, A., and Hokstad, L. M. (2007). Using Mobile Phones to Prepare for University Lectures: Student's Experiences. The Turkish online Journal of Education and Technology (JOJET), Volume (6), Issue (4), Article (9).

[34] AL-Dahshan, Jamal, Ali. (2010). Mobile phone use in education and training: Why? In what? And how? The first seminar in the information and communication technology applications in education and training, King Saud University, College of Education Department of Educational Technology, 12-14 April.

[35] Salem, Ahmed, Mohamed. (2006). A proposed strategy to activate the mobile learning model in the teaching / learning French as a foreign language in smart schools in the light of integration of information and communication technology and economy knowledge. Journal of Studies in university education, university education development center. Ain Shams University, Cairo, August, p 2, pp. 198-283.

[36] Al-Migbil, Ali; Manasir; Mohammad; Arbawi, Ammar; \& Aabach, Ammar. (2010). The development of e-learning environment by using mobile learning technology in order to improve the learning environment of the students at Taibah University. A paper presented to the conference of university's education in the informatics age- aspirations and challenges, Taibah University, Medina.

[37] Assaf, Saleh, Hamad. (2006). introducation to research in the behavioral sciences. $4^{\text {th }}$ ed. Riyadh, Obeikan Library.

[38] Nassuora, A. B. (2012). Students' Acceptance of Mobile Learning for Higher Education in Saudi Arabia. American Academic and Scholarly Research Journal, Vol. 4, No. 2.

[39] Paul, W. W. (2009). Assessing Mobile Learning Effectiveness and Acceptance. PHD, the faculty of the school of business of the George Washington University.

[40] Liaw, S. S., Hatala, M., \& Huang, H. M. (2010). Investigating Acceptance toward mobile learning to assist individual knowledge management: Based on activity theory approach. Computer \& Education, 54, 446-454.

[41] Singh, H. K. D. (2010). Effectiveness pedagogical model using SMS technology. Paper presented at the International Conference on Communication and Media, Melaka, Malaysia.

[42] Yang, Shih-hsien. (2012). Exploring College Students' Attitudes and Self-efficacy of Mobile Learning. Turkish Online Journal of Educational Technology, Vol. 11, Issue 4. Pp. 148-154.

[43] Swan, K., HooftMarkvan't, Kratcoski, A., \& Unger, D. (2005). Uses and effects of mobile computing devices in K-8 classrooms. Journal of Research on Technology in Education, 38 (1), 99-112. Taylor \& Francis. 